JSAP: Journal Syariah and Accounting Public

ISSN: 2622-3538

Available Online at https://journal.umgo.ac.id/index.php/JSAP/index

Vol. 4, No. 2 Desember 2021

DOI: $10.31314 /$ jsap.4.2.66-76.2021

\title{
MANAJEMEN ASET BERGERAK KENDERAAN BERMOTOR PADA DINAS PENGENDALIAN PENDUDUK DAN KELUARGA BERENCANA KABUPATEN GORONTALO
}

Trisusanti Lamangida'. Nahrois Harun ${ }^{2}$

1. 2., Program Studi Administrasi Publik, Universitas Muhammadiyah Gorontalo, Indonesia

Email; tri.susanti@um-gorontalo.ac.id, nahroisharun@gmail.com

Info Artikel: Diterima: 22 November 2021, Disetujui: 24 Sesembar 2021, Publish 24 Desember 2021

\section{Abstract:}

This study aims to determine the movable asset management of motorized vehicles at the Population Control and Family Planning Office of Gorontalo Regency. The results of the study concluded that the management of motorized vehicle movable assets at the Gorontalo District Population Control and Family Planning Office was generally not optimal. In particular, the aspects of use, utilization, safeguarding and maintenance of assets have not been going well and are still far from expectations. Planning for asset requirements and procurement of appraisal, deletion, transfer, administration, and guidance, supervision and control at the Gorontalo District Population and Family Planning Office has been running but has not been maximized. It is recommended that local governments evaluate and improve the management of regional assets in Gorontalo District, especially in terms of use, utilization, security and maintenance of assets.

Keywords: Management, Movable Assets, Motorized Vehicles

\section{Abstrak:}

Penelitian ini bertujuan untuk mengetahui Manajemen Aset Bergerak Kenderaan Bermotor pada Dinas Pengendalian Penduduk dan Keluarga Berencana Kabupaten Gorontalo. Hasil penelitian menyimpulkan bahwa manajemen aset Bergerak Kenderaan Bermotor pada Dinas Pengendalian Penduduk dan Keluarga Berencana Kabupaten Gorontalo secara umum belum maksimal. Terutama aspek penggunaan, pemanfaatan, pengamanan dan pemeliharaan aset belum berjalan dengan baik bahkan masih jauh dari harapan. Perencanaan kebutuhan aset dan pengadaan penilaian, penghapusan, pemindahtanganan, penatausahaan, dan pembinaan, pengawasan, serta pengendalian pada Dinas Pengendalian Penduduk dan Keluarga Berencana Kabupaten Gorontalo sudah berjalan namun belum maksimal. Disarankan Disarankan kepada pemerintah daerah agar melakukan evaluasi dan perbaikan terhadap pengelolaan aset daerah di lingkungan Kabupaten Gorontalo, khususnya dalam hal penggunaan, pemanfaatan, pengamanan dan pemeliharaan aset

Kata kunci : Manajemen, Aset Bergerak, Kenderaan Bermotor

\section{PENDAHULUAN}

Pemerintahan yang baik atau Good

Governance menjadi keinginan semua

bangsa dan Negara di Dunia. Terwujudnya tata pemerintahan yang baik, maka semua instanti pemerintah hendaknya menegakkan prinsip - prinsip good governance dalam penyelenggaraan Negara. Akuntabilitas 
sektor pemerintahan merupakan bentuk pertanggungjawaban pemerintah daerah kepada lembaga-lembaga yang berkepentingan dan terhadap masyarakat yang telah memberikan kepercayaan dan kewenangan untuk menjalankan roda pemerintahan. Bentuk pertanggungjawaban dari masing-masing organisasi, tergantung pada jenis organisasi yang bersangkutan.

Menurut Hariyono (2007). Pengelolaan Aset adalah kegiatan mengelola suatu barang yang dimiliki mulai dari perencanaan, pengadaan, operasi, dan pemeliharaan serta penghapusan.

Gima Sugiama, manajemen aset adalah suatu ilmu dan seni untuk memandu pengelolaan kekayaan yang mencakup proses perencanaan kebutuhan aset, mendapatkan, inventarisasi, legal audit, menilai, mengoperasikan, memelihara, membaharukan atau menghapuskan, hingga mengalihkan aset secara efektif dan efisien.

Menurut Sutrisno (2004) tujuan umum manajemen aset adalah mengarahkan sistem pengelolaan aset sehingga pemanfaatannya efektif dan efisien. Efektif berkaitan dengan sasaran yang tercapai, sedangkan efisien berkaitan dengan biaya yang dikeluarkan. Tujuan khusus dari manajemen aset yaitu meningkatkan kualitas aset, meningkatkan penggunaan dan pemanfaatan aset, meningkatkan kualitas layanan aset dan meningkatkan cakupan layanan aset.
Menurut Siregar (2002:198) ada tiga tujuan utama dari manajemen aset yaitu efisiensi pemanfaatan dan kepemilikan, terjaga nilai ekonomis dan potensi yang dimiliki, objektivitas dalam pengawasan dan pengendalian peruntukkan penggunaan serta alih penguasaan.

Betapa pentingnya pengelolaan aset daerah yang baik dan benar melalui manajemen yang tepat yang berdayaguna dan berhasil guna. Sebab hal ini akan menjadi kekuatan baru bagi kemampuan pemerintah dalam mengelola dan membiayai sendiri pembangunan yang ada di daerahnya, menjadi wujud nyata peningkatan Pendapatan Asli Daerah (PAD). Pada dasarnya Pemerintah daerah dapat mewujudkan sumber pendapatan daerahnya melalui upaya dan langkah strategis, dengan mengoptimalkan pengelolaan barang dan aset milik pemerintah daerah yang selama ini pengelolaan dan manajemen asetnya belum memuaskan. Kurang efektif dan efisiennya pengelolaan barang milik pemerintah daerah, disamping membutuhkan pemerliharaan dan biaya operasional yang tinggi, aset daerah juga merupakan sumberdaya dan modal penting bagi pemerintah daerah dalam penopang mewujudkan pendapatan asli daerah (PAD). Untuk itu diperlukan pengelolaan aset daerah yang baik melalui manajemen aset daerah yang memadai.

Manajemen Aset daerah dilakukan melalalui beberapa pertimbangan 
manajemen aset yang baik; berupa aspek perencanaan kebutuhan, pemanfaatan atau penggunaan, pengamanan dan pemeliharaan, penilaian, penghapusan, pemindahtanganan, pembinaan, pengawasan dan pengendalian, pembiayaan dan tuntutan ganti rugi aset agar pada gilirannya aset daerah mampu memberikan kontribusi optimal bagi penyelenggaraan pemerintah daerah, sehingga arah dan prioritas pembangunan khususnya pada manajemen aset daerah lebih terkordinasi, terintegrasi, tersimplifikasi dan terprogram dengan baik. Pentingnya manajemen aset daerah melalui pengoptimalan aset, dan inventarisasi aset dan dokumentasi di daerah, disebabkan karena banyaknya pelaporan penghibahan tanah ke Negara tetapi tidak disertai bukti surat. Hal ini menunjukkan inventarisasi aset dalam pengoptimalan aset tidak didukung oleh data dan bukti resmi secara hukum.

Ketidakmampuan pemerintah daerah dalam memenej pengelolaan aset ini mengakibatkan kerugian bagi daerah dan masyarakat. dissamping aset yang tidak dikelola dengan baik, untuk untuk kepentingan dan kesejahtreaan rakyat, juga bahkan ironinya aset daerah tidak sedikti yang menjadi mili perseorangan. Pengelolaan aset/ Barang Milik Daerah harus berdasarkan prinsip dasar-dasar manajemen aset daerah. (Budisusilo, 2005).

Beberapa studi kasus terkait pengelolaan aset pada barang milik daerah yang sering disoroti adalah terkait kendaraan bermotor pada Dinas. Pada awalnya pengadaan kendaraan dinas tersebut semata-mata digunakan dalam mendukung kelancaran kegiatan dan pelaksanaan tugas dinas khususnya bagi pegawai pemerintah. Dimana kendaraan tersebut tercatat sebagai barang milik daerah. Namun sering dijumpai penggunaan mobil dinas/sepeda motor, tidak sesuai dengan ketentuan yang ada (Emi Yurisda: 2019).

Menurut Sutrisno (2004) tujuan umum manajemen aset adalah mengarahkan sistem pengelolaan aset sehingga pemanfaatannya efektif dan efisien. Efektif berkaitan dengan sasaran yang tercapai, sedangkan efisien berkaitan dengan biaya yang dikeluarkan. Tujuan khusus dari manajemen aset yaitu meningkatkan kualitas aset, meningkatkan penggunaan dan pemanfaatan aset, meningkatkan kualitas layanan aset dan meningkatkan cakupan layanan aset.

Menurut Siregar (2002:198) ada tiga tujuan utama dari manajemen aset yaitu efisiensi pemanfaatan dan kepemilikan, terjaga nilai ekonomis dan potensi yang dimiliki, objektivitas dalam pengawasan dan pengendalian peruntukkan penggunaan serta alih penguasaan.

Berdasarkan pengamatan awal pada lokasi penelitian bahwa pengelolaan aset daerah khususnya kendaraan bermotor sudah berjalan, namun belum seuai harapan, sebagaimana yang diharapkan 
adalah mencapai daya guna dan hasil guna yang maksimal. Dimana masih banyak ditemui persoalan pengelolaan aset daerah khususnya aset bergerak kendaraan bermotor yang belum optimal. Awalnya jumlah aset bergerak yakni kendaraan beroda dua di Dinas berjumlah 48 buah, dan kendaraan beroda empat berjumlah $19 \mathrm{di}$ kecamatan, dan di Dinas berjumlah 6 buah. Banyaknya pengguna kenderaan Dinas yang kurang memperhatikan pemeliharaan aset, hilangnya surat bukti tanda Nomor Kendaraan (STNK), sertapPengguna aset kendaraan dinas yang tidak memperpanjang surat tanda nomor kendaraaan (STNK) menjadi satu gambaran bahwa pengamanan dan pemeliharaan aset belum berjalan dengan baik, Serta Dinas KB sering mengalami kesulitan dalam menelusuri ataupun mengetahui secara pasti dimana keberadaan kendaraan dinas tersebut. Hal ini menandakan bahwa pemindahtanganan dan penatausahaan barang atau aset daerah belum berjalan dengan baik. Data inventarisir aset yang dimiliki dinas tidak sesuai dengan kondisi barang yang sebenarnya. Fungsi manajemen pembinaan dan pengawasan serta pengendalian aset di Dinas KB belum maksimal

Gima Sugiama, manajemen aset adalah suatu ilmu dan seni untuk memandu pengelolaan kekayaan yang mencakup proses perencanaan kebutuhan aset, mendapatkan, inventarisasi, legal audit, menilai, mengoperasikan, memelihara, membaharukan atau menghapuskan, hingga mengalihkan aset secara efektif dan efisien.

\section{METODE PENELITIAN}

Tempat penelitian dilakukan dilakukan di Dinas Pengendalian Penduduk dan Keluarga Berencana Kabupaten Gororntalo. Desain penelitian ini menggunakan dengan pendekatan penelitian kualitatif dengan jenis penelitian deskriptif

Teknik pengumpulan data melalui observasi, wawancara dan dokumentasi. Sumber data terdiri dari: data primer dan data sekunder. Teknik analisa data peneliti menggunakan analisis data menurut Miles dan Huberman (Sugiyono 2012: 337), Adapun aktivitas dalam analisis data nantinya ialah Reduksi data (Data Reduction), Menampilkan Data (data Display) dan Verifikasi data (Data Verification).

\section{HASIL DAN PEMBAHASAN}

\section{Hasil}

Sebagaimana tujuan dari penelitian ini adalah untuk mengetahui dan memperoleh gambaran yang objektif tentang Manajemen Aset bergerak kenderaan bermotor pada Dinas Pengendalian Penduduk dan Keluarga Berencana Kabupaten Gorontalo. Maka untuk menjawab tujuan penelitian ini, dilakukan penelusuran melalui wawancara mendalam kepada informan terkait permasalahan 
penelitian. dapat dideskripsikan sebagai berikut:

\section{Perencanaan Kebutuhan Aset}

Pelaksanaan (actuating) Penggunaan aset yang dilakukan oleh pengguna/kuasa pengguna dalam mengelola dan menata usahakan barang milik daerah sesuai dengan tugas dan fungsi satuan kerja perangkat daerah (SKPD).

Berdasarkan hasil wawancara di atas yang telah dilakukan kepada informan yang terdiri atas Penyuluh KB Kecamatan Telaga Biru, dan Kepala Bidang dan kesejahteraan Keluarga dinas PPKB Kabupaten Gorontalo, Kasubag Umum da Kepegawaian, Kabid Pengendalian KB Kabupaten Goorntalo, Penyuluh KB Kecamatan Limboto, serta Kasi Pemberdayaan dan Ekonomi Keluarga, maka peneliti dapat menyimpulkan bahwa proses perencanaan kebutuhan asset bergerak (kenderaan bermotor) Di Dinas KB sudah berjalan tetapi belum maksimal.

Tahapan manajemen atau alur manajemen asset (inventarisasi asset, legal audit, penilaian, optimasi dan pengembangan sima) belum sesuai harapan, ada asset yang sudah tidak terpakai seharusnya dilelang agar asset-aset ini tertata dengan baik

\section{Pengadaan}

Manajemen pengadaan aset adalah upaya merencanakan, melaksanakan, dan mengendalikan seluruh rangkaian kegiatan dari awal hingga akhir untuk mendapatkan aset berupa barang atau jasa baik yang dipenuhi sendiri, maupun oleh pihak luar sebagai penyedia/pemasok secara epektif dan efisien. Pengadaan barang daerah di Dinas pengendalian penduduk dan KB Kab. Gorontalo pada pelaksanaannya umumnya belum sesuai harapan dan tujuan awal. Masih jauh dari tertib administrasi pengadaan barang daerah; Tertib administrasi pengelolaan barang daerah, serta pendayagunaan barang daerah secara maksimal.

Berdasarkan hasil wawancara di atas yang telah dilakukan kepada informan yang terdiri atas Penyuluh KB Kecamatan Telaga Biru, Kabid Pengendalian KB Kabupaten Goorntalo, Kepala Bidang dan kesejahteraan Keluarga dinas PPKB Kabupaten Gorontalo, Penyuluh KB Kecamatan Limboto, serta Kabid Pengendalian KB Kecamatan Limboto, maka peneliti dapat menyimpulkan bahwa pengadaan asset bergerak (kenderaan bermotor) di Dinas KB sudah berjalan tetapi belum maksimal.

\section{Penggunaan dan Pemanfaatan}

$$
\text { Penggunaan dan Pemanfaatan aset }
$$
adalah pendayagunaan Barang Milik Negara/Daerah oleh pihak lain dalam jangka waktu tertentu dalam rangka peningkatan penerimaan negara bukan pajak/pendapatan daerah dan sumber pembiayaan lainnya.

Berdasarkan hasil wawancara di atas yang telah dilakukan kepada informan yang terdiri atas Penyuluh KB Kecamatan Limboto, serta Kabid Pengendalian KB Kecamatan Limboto dan Penyuluh KB Kecamatan Telaga Biru 
dan Kabid Pengendalian KB Kabupaten Goorntalo, Kasubag Perencanaan dinas PPKB Kabupaten Gorontalo, maka peneliti dapat menyimpulkan bahwa Penggunaan dan Pemanfaatan aset di Dinas KB melalui tahapan manajemen atau alur manajemen asset (inventarisasi asset, legal audit, penilaian, optimasi dan pengembangan sima) Di Dinas KB sudah berjalan tetapi belum maksimal

\section{Penilaian aset}

Penilaian Aset diartikan sebagai proses penilaian seorang penilai dalam memberikan suatu opini nilai suatu aset baik berwujud maupun tidak berwujud, berdasarkan hasil analisa terhadap faktafakta yang obyektif dan relevan dengan menggunakan metode dan prinsipprinsip penilaian yang berlaku.

Pelaksanaan (actuating) Penilaian aset merupakan suatu proses kegiatan yang selektif didasarkan pada data/fakta yang objektif dan relefan dengan menggunakan metode/teknis tertentu untuk memperoleh nilai barang milik daerah.

\section{Pengamanan dan Pemeliharaan}

Menurut A. Gima Sugiama (2013: 240), pemeliharaan aset adalah sebuah sisrem yang mencakup kombinasi dari sekumpulan akivitas yang dilengkapi oleh beragam sumberdaya untuk menjamin agar aset bersangkutan dapat berfungsi sebagaimana diharapkan. Pengamanan Barang Milik Daerah ialah kegiatan berupa tindakan pengendalian dalam pengurusan barang milik daerah dalam bentuk fisik, administratif dan tindakan upaya hukum Berdasarkan hasil wawancara di atas yang telah dilakukan kepada informan yang terdiri atas penyuluh KB Kec Telaga Biru, Kasubag Umum dan Kepegawaian, serta Kasie Pengelola data dan Informasi Keluarga Dinas PPKB Kabupaten Gorontalo, dan penyuluh KB Kec Telaga Biru, Kasubag KB dan Kesejahteraan keluarga, kasubag Umum dan Kepegawaian, serta Kasie pemberdayaan dan ekonomi keluarga, maka peneliti dapat menyimpulkan bahwa pengamanan dan pemeliharaan aset bergerak $\mathrm{Di}$ Dinas KB belum berjalan dengan baik

Terkait pengamanan dan pemeliharaan berdasarkan hasil wawancara yang telah dilakukan kepada informan dapat bahwa pengamanan dan pemeliharaan aset bergerak $\mathrm{Di}$ Dinas KB belum berjalan dengan baik.

\section{Penghapusan dan Pemindahtanganan}

Berdasarkan hasil wawancara di atas yang telah dilakukan kepada informan yang terdiri atas penyuluh KB Kec Telaga Biru, Kasubag Umum dan Kepegawaian, serta Kasie Pengelola data dan Informasi Keluarga Dinas PPKB Kabupaten Gorontalo, dan penyuluh KB Kec Telaga Biru, Kasubag KB dan Kesejahteraan keluarga, kasubag Umum dan Kepegawaian, serta Kasie pemberdayaan dan ekonomi keluarga,maka peneliti dapat menyimpulkan bahwa penghapusan dan pemindahtan gan aset 
bergerak Di Dinas KB belum berjalan dengan baik

Penghapusan dan pemindahtanganan Asset merupakan bagian dari Controling pada pengelolaan aset bergerak kendaraan di Dinas KB pernah dialihkan di pihak berdasarkan hasil wawancara yang telah dilakukan kepada informan dapat di simpulkan bahwa penghapusan dan pemindahtangan aset bergerak Di Dinas KB belum berjalan dengan baik. Belum pernah dilakukan pengendalian kenderaan kepihak lain tapi hanya mengikuti system lelang atau pemusnahan yang sudah mendapat persetujuan Bupati

\section{Pembinaan, Pengawasan dan} Pengendalian

Penghapusan dan pemindahtangan aset bergerak $\mathrm{Di}$ Dinas KB belum berjalan dengan baik. Hasil penelitian bahwa secara umum belum terkait pengawasan pada pengunaan kenderaan dinas berjalan sesuai harapan. karena ada juga beberapa asset yang tidak diketahui keberadaannya, termasuk saya Ketika mengusulkan leptop yang baru tidak bisa karena katanya ditelaga biru masih ada leptop tercatat sebagai asset sehingga perlu inventarisasi Kembali terhadap asset-aset yang ada didinas. Tidak sesuai harapan, alasan banyak kekurangan pada kenderaan tidak diperdulikan atau kurang perhatian oleh dinas. Pembinaan merupakan usaha atau kegiatan melalui pedoman, bimbingan, pelatihan, dan supervise. Pengawasan pengelolaan aset selama umur ekonomis selama ini belum maksimal. sehingg tujuan manajemen aset untuk tetap menjaga aset agar dapat membantu proses pencapaian tujuan organisasi yang memiliki aset tersebut belum berhasil.

\section{Pembahasan}

Penelitian ini bertujuan untuk mengetahui manajemen aset daerah pada dinas Kependudukan dan Keluarga Berencana Kabupaten Gorontalo. Pada bagian ini akan diuraikan analisis hasil wawancaa penelitian yang diperoleh. Adapun hal-hal yang dibahas yaitu manajemen aset daerah dalam pelaksanaannya, sebagimana teori yang dikutip oleh A. Gima Sugiama (2013: 240), dari pendapat beberapa ahli. Dikaitkan dengan teori manajemen (Planning, Organization, Actuating, Controling) POAC menurut Terry 2012, Pembahasan untuk masing-masing indicator adalah sebagai berikut:

\section{Perencanaan Kebutuhan Aset}

Tujuan perencanaan kebutuhan aset adalah memperjelas arah dalam pengadaan aset, memastikan agar operasi aset dapat dilakukan sesuai kebutuhan, menyediakan aset yang berfungsi secara efektif dan efisien, dan memilih cara paling tepat untuk menyediakan aset tersebut. Terkait perencanaan kebutuhan aset dalam manajemen aset daerah di Dinas Kependudukan dan Keluarga Berencana, berdasarkan hasil wawancara dengan 
informan dapat disimpulkan bahwa proses perencanaan kebutuhan asset bergerak (kenderaan bermotor) Di Dinas KB sudah berjalan tetapi belum maksimal. Temuan penelitian terkait perencanaan kebutuhan aset Kendaraan bermotor di dinas KB itu sudah sesuai dengan perencanaan yang ada dinas, karena memang sudah melalui usulan dan hasil perencanaan yang ada di dinas pengendalian penduduk dan KB Kab.Gorontalo. Adanya pembayaran pajak motor serta perbaikan masih ditanggung oleh pengguna yang harusnya itu ditanggung oleh Negara.

Planning meliputi pengaturan tujuan dan mencari cara bagaimana untuk mencapai tujuan pengelolaan aset tersebut. Planning telah dipertimbangkan sebagai fungsi utama manajemen dan meliputi segala sesuatu yang manajer kerjakan. Membuat keputusan biasanya menjadi bagian dari perencanaan karena setiap pilihan dibuat berdasarkan proses penyelesaian setiap rencana. Planning penting karena banyak berperan menggerakan fungsi manajemen yang lain.

\section{Pengadaan}

Manajemen pengadaan aset adalah upaya merencanakan, melaksanakan, dan mengendalikan seluruh rangkaian kegiatan dari awal hingga akhir untuk mendapatkan aset berupa barang atau jasa baik yang dipenuhi sendiri, maupun oleh pihak luar sebagai penyedia/pemasok secara epektif dan efisien. Terkait pengadaan asset bergerak (kenderaan bermotor) pada Dinas Pengendalian Penduduk Dan Keluarga Berencana Kabupaten Gorontalo, berdasarkan hasil wawancara dengan di simpulkan bahwa pengadaan asset bergerak (kenderaan bermotor) di Dinas KB sudah berjalan tetapi belum maksimal.

Pelaksanaan (actuating) dalam pengadaan aset berdasarkan keputusan Presiden Nomor 80 Tahun 2003 dan perubahannya Peraturan Presiden Nomor 54 Tahun 2010. Pengadaan barang daerah dapat dipenuhi dengan cara pengadaan/pemborongan pekerjaan, membuat sendiri (swakelola), penerimaan (hiba atau bantuan/sumbangan atau. Pengadaan barang milik daerah dilaksanakan berdasarkan prinsip efisien, efektif, transparan dan terbuka, bersaing, adil, dan akuntabel dilakukan sesuai dengan ketentuan peraturan perundang-undangan. Pengadaan barang daerah di Dinas pengendalian penduduk dan KB Kab. Gorontalo pada pelaksanaannya umumnya belum sesuai harapan dan tujuan awal. Masih jauh dari tertib administrasi pengadaan barang daerah; Tertib administrasi pengelolaan barang daerah, serta pendayagunaan barang daerah secara maksimal.

\section{Penggunaan dan Pemanfaatan}

Penggunaan dan Pemanfaatan aset adalah pendayagunaan Barang Milik 
Negara/Daerah oleh pihak lain dalam jangka waktu tertentu dalam rangka peningkatan penerimaan negara bukan pajak/pendapatan daerah dan sumber pembiayaan lainnya. Terkait Penggunaan dan Pemanfaatan aset di Dinas Pengendalian Penduduk Dan Keluarga Berencana Kabupaten Gorontalo berdasarkan hasil wawancara dengan informan dapat disimpulkan bahwa Penggunaan dan Pemanfaatan aset di Dinas KB melalui tahapan manajemen atau alur manajemen asset (inventarisasi asset, legal audit, penilaian, optimasi dan pengembangan sima) Di Dinas KB sudah berjalan tetapi belum maksimal.

\section{Pelaksanaan}

(actuating)

Penggunaan aset yang dilakukan oleh pengguna/kuasa pengguna dalam mengelola dan menata usahakan barang milik daerah sesuai dengan tugas dan fungsi satuan kerja perangkat daerah (SKPD). Barang milik daerah ditetapkan status penggunaannya untuk penyelenggaraan tugas pokok dan fungsi Satuan Kerja Perangkat Daerah dan dapat dioperasikan oleh pihak lain dalam rangka mendukung pelayanan umum sesuai tugas pokok dan fungsi Satuan Kerja Perangkat Daerah yang bersangkutan. Kenyataannya tahapan manajemen atau alur manajemen asset (inventarisasi asset, legal audit, penilaian, optimasi dan pengembangan sima) belum sesuai harapan, ada asset yang sudah tidak terpakai seharusnya dilelang agar asset-aset ini tertata dengan baik.

\section{Penilaian aset}

Penilaian Aset diartikan sebagai proses penilaian seorang penilai dalam memberikan suatu opini nilai suatu aset baik berwujud maupun tidak berwujud, berdasarkan hasil analisa terhadap faktafakta yang obyektif dan relevan dengan menggunakan metode dan prinsipprinsip penilaian yang berlaku. Terkait penilaian aset di Dinas Pengendalian Penduduk Dan Keluarga Berencana Kabupaten Gorontalo Berdasarkan hasil wawancara di atas yang telah dilakukan kepada informan yang terdiri atas Kasubag umum dan kepegawaian dinas PPKB, Kasubag Perencanaan Keuangan dinas PPKB serta Kabid Pengendalian KB Kecamatan Limboto, Penyuluh KB Kec. Telaga, maka peneliti dapat menyimpulkan bahwa penilaian aset Di Dinas KB belum berjalan dengan baik

\section{Pelaksanaan (actuating) Penilaian} aset merupakan suatu proses kegiatan yang selektif didasarkan pada data/fakta yang objektif dan relefan dengan menggunakan metode/teknis tertentu untuk memperoleh nilai barang milik daerah. Pada tahap ini pihak asset management menentukan nilai aset yang dimiliki sehingga perusahaan mengetahui dengan jelas nilai kekayaan yang dimiliki, yang dialihkan maupun yang dihapuskan.

\section{Pengamanan dan Pemeliharaan}

Pengamanan dan pemeliharaan aset merupakan bagian controlling adalah yang 
mencakup kombinasi dari sekumpulan akivitas yang dilengkapi oleh beragam sumberdaya untuk menjamin agar aset bersangkutan dapat berfungsi sebagaimana diharapkan. Pengamanan Barang Milik Daerah ialah kegiatan berupa tindakan pengendalian dalam pengurusan barang milik daerah dalam bentuk fisik, administratif dan tindakan upaya hukum. Terkait pengamanan dan pemeliharaan berdasarkan hasil wawancara yang telah dilakukan kepada informan dapat disimpulkan bahwa pengamanan dan pemeliharaan aset bergerak Di Dinas KB belum berjalan dengan baik. Tujuan dilakukan pemeliharaan atas barang milik adalah untuk menjaga kondisi dan memperbaiki semua barang milik daerah agar selalu dalam keadaan baik dan layak serta siap digunakan secara berdaya guna dan berhasil guna.

\section{Penghapusan dan Pemindahtanganan}

$$
\text { Penghapusan }
$$

pemindahtanganan Asset merupakan bagian dari Controling pada pengelolaan aset bergerak kendaraan di Dinas KB pernah dialihkan di pihak berdasarkan hasil wawancara yang telah dilakukan kepada informan dapat di simpulkan bahwa penghapusan dan pemindahtangan aset bergerak Di Dinas KB belum berjalan dengan baik. Belum pernah dilakukan pengendalian kenderaan kepihak lain tapi hanya mengikuti system lelang atau pemusnahan yang sudah mendapat persetujuan Bupati.

\section{Pembinaan, Pengawasan dan Pengendalian}

Pembinaan, Pengawasan dan Pengendalian, merupakan tugas dan tanggungjawab organisasi dalam mencapai tujuan organisasi. Berdasarkan hasil wawancara di atas yang telah dilakukan kepada informan yang terdiri atas penyuluh KB Kec Telaga Biru, Kasubag Umum dan Kepegawaian, serta Kasie Pengelola data dan Informasi Keluarga Dinas PPKB Kabupaten Gorontalo, dan penyuluh KB Kec Telaga Biru, Kasubag KB dan Kesejahteraan keluarga, kasubag Umum dan Kepegawaian, serta Kasie pemberdayaan dan ekonomi keluarga, maka peneliti dapat menyimpulkan bahwa penghapusan dan pemindahtangan aset bergerak Di Dinas KB belum berjalan dengan baik. Hasil penelitian bahwa secara umum belum terkait pengawasan pada pengunaan kenderaan dinas berjalan sesuai harapan. karena ada juga beberapa asset yang tidak diketahui keberadaannya, termasuk saya Ketika mengusulkan leptop yang baru tidak bisa karena katanya ditelaga biru masih ada leptop tercatat sebagai asset sehingga perlu inventarisasi Kembali terhadap asset-aset yang ada didinas. Tidak sesuai harapan, alasan banyak kekurangan pada kenderaan tidak diperdulikan atau kurang perhatian oleh dinas. Pembinaan merupakan usaha atau kegiatan melalui pedoman, bimbingan, pelatihan, dan 
supervise. Pengawasan pengelolaan aset selama umur ekonomis selama ini belum maksimal. sehingg tujuan manajemen aset untuk tetap menjaga aset agar dapat membantu proses pencapaian tujuan organisasi yang memiliki aset tersebut belum berhasil.

\section{KESIMPULAN}

Disimpulkan bahwa manajemen aset bergerak Kenderaan bermotor pada Dinas Pengendalian Penduduk dan Keluarga Berencana Kabupaten Gorontalo belum maksimal. Terutama aspek penggunaan, pemanfaatan, pengamanan dan pemeliharaan aset belum berjalan dengan baik bahkan masih jauh dari harapan. Perencanaan kebutuhan aset dan pengadaan penilaian, penghapusan, pemindahtanganan, penatausahaan, dan pembinaan, pengawasan, serta pengendalian pada Dinas Pengendalian Penduduk dan Keluarga Berencana Kabupaten Gorontalo sudah berjalan namun belum maksimal

\section{SARAN}

Disarankan kepada pemerintah daerah agar melakukan evaluasi dan perbaikan terhadap pengelolaan aset daerah di lingkungan Kabupaten Gorontalo, khususnya dalam hal penggunaan, pemanfaatan, pengamanan dan pemeliharaan aset bergerak kenderaan bermotor.

\section{Referensi}

A.Gima Sugiama (2013). Manajemen Aset Pariwisata Bandung : Guardaya.

A. Gima Sugiama. (2013). Metode Riset Bisnis dan Manajemen. Edisi Pertama, Bandung: Guardaya Intimarta.

Budisusilo, S. 2005. Penilaian dan Pengelolaan Aset Daerah Dalam Pembangunan Daerah Seminar Nasional MEP UGM [Makalah]. Yogyakarta. Universitas Gajah Mada

Haryono, A. (2007). Modul Prinsip dan Teknik Manajemen Kekayaan Negara. Tangerang: Badan Pendidikan dan Pelatihan Keuangan, Pusdiklat Keuangan Umum.

Siregar D. Doli (2004) Manajemen Aset Jakarta; Satyatama Graha Tara

Siregar, D. D. (2004). Manajemen Aset. Strategi Penataan Konsep Pembangunan Berkelanjutan Secara Nasional dalam Konteks Kepala Daerah Sebagai CEO's pada Era Globalisasi dan Otonomi Daerah. PT. Gramedia Pustaka Utama

Sutrisno Hadi, Metodologi Research 2, Andi Offset, Yogyakarta, 2004

Terry, G. R., \& Franklin, S. G. (1994). Princples Of Management. Richard D. Irwin

Yurisda, Emi. 2019. Pengelolaan Mobil Dinas Sebagai Barang Milik Daerah Menurut Permendagri No. 19 Tahun 2016 di Kabupaten Aceh Selatan. Skripsi, Departemen Hukum Tata Negara Fakultas Syariah dan Hukum, Universitas Islam Negeri Ar-Ranry Darussalam, Banda Aceh 